\title{
Pengaruh Penggunaan Media Terhadap Hasil Kreatif Produksi Variety Show Mission X Trans TV
}

\author{
Rosiana Andhikasari \\ Universitas Bina Sarana Informatika \\ e-mail: rosianaandhikasari@gmail.com
}

\begin{abstract}
Cara Sitasi: Andhikasari, R. (2019). Pengaruh Penggunaan Media Terhadap Hasil Kreatif Produksi Variety Show Mission X Trans TV. Jurnal Komunikasi, 10(1), 77-82.
\end{abstract}

\begin{abstract}
This study is aimed to investigate the effect of media uses towards the result of creative production of variety show Mission X Trans TV on resident of Perumahan Griya Permata Asri Tulungagung, East Java. Sub variable of media uses such as frequency, intensity, duration, media content, the individual's relationship with media. Related literature used in this research is uses and gratification theory. This research belongs to quantitative research. Sample employed here is 78 resident of Perumahan Griya Permata Asri Tulungagung, East Java. In gathering the data, questionnaire is used and the result is counted by using likert scale. Moreover, to make the data valid, some tests are also used. They are validity test and reliability test. Furthermore, the data are analyzed by using double linier regression analysis. From the results of data analysis and discussion it was found that the variable of media uses $(X)$, have a significant effect on creative production $(Y)$. The contribution of media uses amounted to 45,7\%, the remaining approximately influenced by other factors besides these variable. The existence of a good escapits needs effect of resident perceives the success of production team of Mission X Trans $T V$. To obtain a positive perception of the public, production team of Mission X Trans TV must improve the quality of program television.
\end{abstract}

Keywords: media uses, creative production, variety show

\section{PENDAHULUAN}

Televisi sebagai salah satu bentuk media massa dengan kelebihan yang dimiliki kemudian tidak menjadikan saingan dari media massa lainnya (N.R.A, 2010). Televisi telah menjalani proses perkembangan yang cukup lama sebelum menjadi media komunikasi massa seperti saat ini, dimulai pada tahun 1840 oleh Peter (Effendy, 2003). Sejak tahun 1925, televisi mulai diperkenalkan ke masyarakat umum, dan pada tahun 1940 televisi mengalami perkembangan yang cukup pesat menjadi industri besar. Setelah perang dunia 2 berakhir, televisi berkembang dari yang awalnya hitam putih menjadi televisi berwarna pada tahun 1967, sehingga semakin menggeser posisi radio sebagai alat komunikasi massa favorit masyarakat .

Tulungagung merupakan sebuah kabupaten di Jawa Timur. Letak wilayahnya yang jauh dari kota besar membuat masyarakatnya mendapatkan hiburan yang lebih sedikit dibandingkan dengan masyarakat yang tinggal di kota besar. Hiburan yang banyak digunakan oleh masyarakat Tulungagung pada umumnya adalah media elektronik, salah satunya adalah televisi.
Penggunaan media pada masyarakat Indonesia dapat dikatakan cukup tinggi karena mada era modern seperti saat ini, masyarakat tidak lepas dari media, baik itu media elektronik, cetak, maupun online. Semakin banyak penonton suatu program acara televisi menunjukkan kualitas kreatif produksi acara tersebut semakin baik. Begitu pula dalam aspek kebutuhan khalayak, suatu program akan ditonton oleh banyak orang jika penonton merasa kebutuhan yang diinginkan dalam menonton suatu program acara tercukupi.

Televisi bersifat audible dan visible yaitu dapat dilihat dan dapat didengar serta terdapat programprogram yang dihadirkan televisi mulai dari berita, Talk Show, Reality Show, Infotaiment, Variety Show dan program-program lainnya. Program tersebut lalu menyatu untuk menarik perhatian khalayak dan khalayak tersebut yang menentukan program apa yang mereka pilih sesuai dengan kebutuhan masing-masing khalayak tersebut (Rahmadhani, 2014). Salah satu program Variety Show yang banyak diminati anak muda saat ini adalah Mission X yang tayang di Trans TV. Sehingga perlu dilihat aspek apa saja dari sebuah tayangan variety show yang membuat masyarakat tertarik untuk menonton. Salah satunya adalah 
bagian kreatif produksi. Karena sebuah variety show sangat bergantung pada bagian tim kreatif, bagaimana membuat suatu acara menjadi menarik dan layak untuk disuguhkan kepada pemirsa.

Berdasarkan latar belakang masalah diatas, maka rumusan masalah dalam penelitian ini dapat digunakan adalah bagaimana pengaruh penggunaan media dan kebutuhan khalayak terhadap hasil kreatif produksi variety show Mission X Trans TV, dengan fokus penelitian sebagai berikut:

1. Bagaimana penggunaan media pada warga Perumahan Griya Permata Asri Tulungagung?

2. Bagaimana hasil produksi kreatif variety show Mission X Trans TV?

3. Bagaimana pengaruh penggunaan media terhadap hasil produksi kreatif variety show Mission X Trans TV?

\section{Model Uses and Gratification}

Model ini memulai dengan lingkungan sosial (social environnment) yang menentukan kebutuhan kita. Lingkungan sosial tersebut meliputi ciri-ciri afiliasi kelompok dan ciri-ciri kepribadian. Kebutuhan individual (individual needs) dikategorisasikan menjadi cognitive needs, affective needs, personal integrative needs, dan tensionrelease or escape needs (Suparmo, 2017). Penjelasannya adalah:

1. Cognitive needs (kebutuhan kognitif)

Kebutuhan yang berkaitan dengan peneguhan informasi, pengetahuan dan pemahaman mengenai lingkungan. Kebutuhan ini didasarkan pada hasrat untuk memahami dan menguasai lingkungan, juga memuaskan rasa penasaran dan dorongan untuk penyelidikan.

2. Affective needs (kebutuhan afektif)

Kebutuhan yang berkaitan dengan peneguhan pengalaman-pengalaman yang estetis, menyenangkan, dan emosianal.

3. Personal integrative needs (kebutuhan personal secara integratif)

Kebutuhan yang berkaitan dengan peneguhan kredibilitas, kepercayaan, stabilitas, dan status individual. Hal-hal tersebut diperoleh dari hasrat akan harga diri.

4. Escapits needs (kebutuhan pelepasan)

Kebutuhan yang berkaitan dengan upaya menghindarkan tekanan, ketegangan, dan hasrat akan keanekaragaman.

Adapun hipotesis yang akan diuji dalam penelitian ini adalah:

1. $\mathrm{Ha}_{1}$ :Penggunaan media masyarakat Perumahan Griya Permata Asri Tulungagung dalam menonton tayangan Mission X Trans TV tinggi.
2. $\mathrm{Ha}_{2}$ :Hasil produksi kreatif pada tayangan variety show Mission X Trans TV membuat penonton merasa puas dan terhibur.

3. $\mathrm{Ha}_{3}$ : Ada pengaruh yang signifikan antara penggunaan media terhadap hasil produksi kreatif tayangan variety show Mission X Trans TV pada masyarakat Perumahan Griya Permata Asri Tulungagung.

\section{METODOLOGI PENELITIAN}

Penelitian ini menggunakan metode penelitian kuantitatif deskriptif. Adapun populasi yang menjadi subjek penelitian ini adalah 360 warga di Perumahan Griya Permata Asri Kabupaten Tulungagung, Jawa Timur. Untuk menentukan besarnya sampel, dalam penelitian ini digunakan rumus Slovin (Ruslan, 2006), dengan jumlah yang besar sehingga dapat dirumuskan sebagai berikut:

$$
n=\frac{N}{1+\left(N \times e^{2}\right)}
$$

Keterangan:

$\mathrm{n}$ : ukuran sampel

$\mathrm{N}$ : ukuran populasi

e : persentase ketidaktelitian karena kesalahan pengambilan sampel

Berdasarkan rumus tersebut maka penetapan jumlah sampel dalam penelitian ini didapatkan hasil 78 responden sebagai sample penelitian. Sesuai dengan skala yang dipilih yaitu skala likert dengan analisis kuantitatif, maka penilaian terhadap jawaban responden dari kuisioner disajikan dengan 1 sampai dengan 5 pilihan respon (fivepoint) disertai dengan skor nilai yang telah ditentukan oleh peneliti. Adapun lima pilihan untuk masing-masing kategori tersebut adalah:
a) Sangat setuju (SS)
b) Setuju (S)
$=5$
c) Kurang setuju (KS)
$=4$
d) Tidak setuju (TS)
e) Sangat tidak setuju (STS)
$=2$
$=1$

Instrumen tersebut perlu diuji lebih lanjut untuk menghasilkan data yang akurat. Dalam penelitian ini digunakan uji validitas dan reliabilitas instrumen. Metode analisis data yang digunakan dalam penelitian ini adalah statistik deskriptif dan analisa regresi berganda (multiple regresion) (Haslinda, 2016). Metode analisis statistik inferensial bertujuan untuk menganalisis data sampel yang hasilnya diberlakukan untuk populasi.

1. Regresi Linier Berganda
a. Uji F
b. Uji t 


\section{HASIL DAN PEMBAHASAN}

Berdasarkan penghitungan spss, dapat diketahui bahwa semua item pertanyaan memiliki nilai $r$ hitung $>$ r tabel $(0,227)$ atau nilai signifikansi < alpha $(0,05)$ sehingga dapat dikatakan semua item pertanyaan telah valid. Berdasarkan penghitungan menggunakan spss dapat diketahui bahwa semua variabel tersebut memiliki nilai koefisien Alpha Cronbach lebih besar dari 0,6 sehingga dapat dikatakan instrumen pertanyaan yang digunakan dalam penelitian ini sudah reliabel atau dapat diandalkan.

Dari hasil penghitungan kuisioner pada variabel penggunaan media, menunjukkan bahwa penggunaan media pada warga Perumahan Griya Permata Asri Tulungagung dapat dikatakan tinggi, hal ini dapat dilihat dari jawaban yang diberikan responden, mayoritas menonton tayangan Mission $\mathrm{X}$ dari awal sampai akhir, dan mengikuti setiap segmen dan ikut berpartisipasi secara aktif dalam media sosial.

Tabel 1. Penggunaan Media

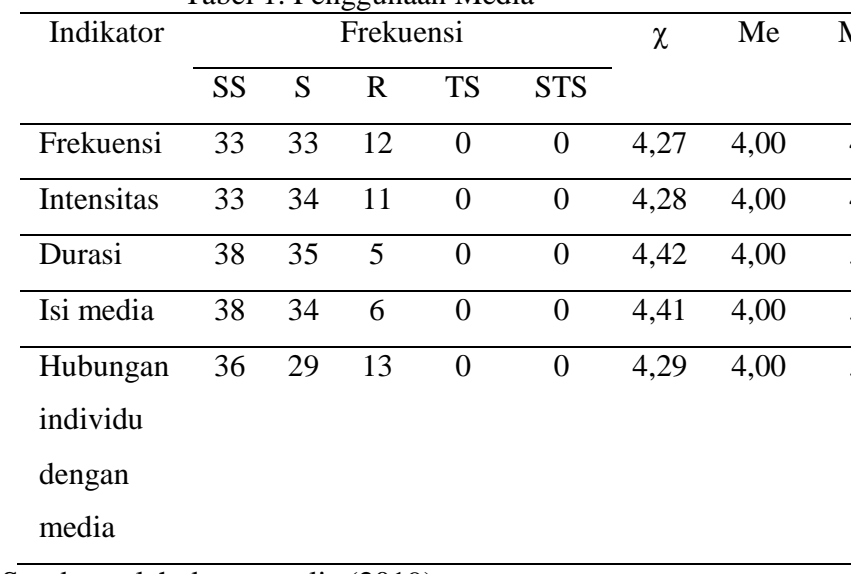

Sumber: olah data penulis (2019)

Keterangan:

Indikator

: Sub Variabel Penggunaan

Media (X)

SS $\quad:$ Sangat Sering

$\mathrm{S} \quad$ : Sering

R : Ragu-ragu

TS : Tidak Sering

STS : : Sangat Tidak Sering

$\chi \quad: \quad$ Nilai Mean

Me : Nilai Median

Indikator frekuensi menunjukkan kesimpulan bahwa mayoritas responden menyatakan frekuensi menonton tayangan Mission $\mathrm{X}$ tinggi, jika diprosentase menunjukkan bahwa responden memberikan respon yang bagus terhadap indikator frekuensi dengan nilai tertinggi 42,3\%. Mean yaitu rata-rata responden dengan nilai 4,27 menunjukkan bahwa responden memiliki frekuensi yang tinggi dalam menonton tayangan Mission X. Median yaitu nilai tengah responden dengan nilai 4,00 menunjukkan bahwa respoden memiliki frekuensi yang sering dalam menonton tayangan Mission X. Mode/modus yaitu nilai data yang memiliki frekuensi tertinggi dengan nilai 4 menunjukkan bahwa responden menganggap indikator frekuensi memiliki nilai yang positif.

Indikator intensitas menunjukkan kesimpulan bahwa mayoritas responden menyatakan intensitas menonton tayangan Mission $\mathrm{X}$ tinggi, jika diprosentase menunjukkan bahwa responden memberikan respon yang bagus terhadap indikator intenstias dengan nilai tertinggi 43,6\%. Mean yaitu rata-rata responden dengan nilai 4,28 menunjukkan bahwa responden memiliki intensitas yang tinggi dalam menonton tayangan Mission X. Median yaitu nilai tengah responden dengan nilai 4,00 menunjukkan bahwa respoden memiliki intensitas yang sering dalam menonton tayangan Mission X. Mode/modus yaitu nilai data yang memiliki frekuensi tertinggi dengan nilai 4 menunjukkan bahwa responden menganggap indikator intensitas memiliki nilai yang positif.

Møndikator durasi menunjukkan kesimpulan bahwa mayoritas responden menyatakan durasi menonton tayangan Mission $\mathrm{X}$ tinggi, jika diprosentase ${ }^{4}$ menunjukkan bahwa responden memberikan 4respon yang bagus terhadap indikator durasi dengan

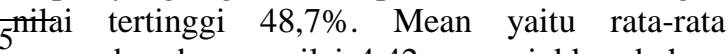
5 responden dengan nilai 4,42 menunjukkan bahwa 5responden memiliki durasi yang tinggi dalam

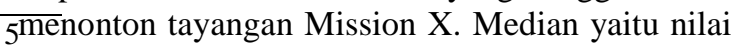
tengah responden dengan nilai 4,00 menunjukkan bahwa respoden memiliki durasi yang sering dalam menonton tayangan Mission X. Mode/modus yaitu nilai data yang memiliki frekuensi tertinggi dengan nilai 5 menunjukkan bahwa responden menganggap indikator durasi memiliki nilai yang sangat positif.

Indikator isi media (komponen acara seperti pembawa acara, konsep acara, lokasi,dll) menunjukkan kesimpulan bahwa mayoritas responden menyatakan isi media tayangan Mission $\mathrm{X}$ tinggi, jika diprosentase menunjukkan bahwa responden memberikan respon yang bagus terhadap indikator isi media dengan nilai tertinggi 48,7\%. Mean yaitu rata-rata responden dengan nilai 4,41 menunjukkan bahwa responden menyatakan isi media tayangan Mission X sering ditonton. Median yaitu nilai tengah responden dengan nilai 4,00 menunjukkan bahwa respoden menonton isi media tayangan Mission X. Mode/modus yaitu nilai data yang memiliki frekuensi tertinggi dengan nilai 5 menunjukkan bahwa responden menganggap indikator isi media memiliki nilai yang sangat positif. 
Indikator hubungan individu dengan media menunjukkan kesimpulan bahwa mayoritas responden menyatakan hubungan individu dengan media pada tayangan Mission X tinggi, jika diprosentase menunjukkan bahwa responden memberikan respon yang bagus terhadap indikator hubungan individu dengan media dengan nilai tertinggi $46,2 \%$. Mean yaitu rata-rata responden dengan nilai 4,29 menunjukkan bahwa responden memiliki hubungan individu dengan media yang tinggi dalam tayangan Mission X. Median yaitu nilai tengah responden dengan nilai 4,00 menunjukkan bahwa respoden memiliki hubungan individu dengan media yang sering dalam tayangan Mission X. Mode/modus yaitu nilai data yang memiliki frekuensi tertinggi dengan nilai 5 menunjukkan bahwa responden menganggap indikator hubungan individu dengan media memiliki nilai yang sangat positif.

\begin{tabular}{|c|c|c|c|c|c|c|}
\hline \multirow[t]{2}{*}{ Indikator } & \multicolumn{5}{|c|}{ Frekuensi } & \multirow[t]{2}{*}{$\chi$} \\
\hline & SS & $\mathrm{S}$ & $\mathrm{R}$ & TS & STS & \\
\hline \multicolumn{7}{|l|}{ Continuity } \\
\hline -konsep & 49 & 16 & 11 & 1 & 1 & 4,40 \\
\hline -dialog & 51 & 17 & 6 & 3 & 1 & 4,46 \\
\hline \multicolumn{7}{|l|}{ Compsition } \\
\hline -gambar & 47 & 20 & 7 & 3 & 1 & 4,40 \\
\hline -warna & 44 & 30 & 2 & 2 & 0 & 4,49 \\
\hline $\begin{array}{l}\text { Camera } \\
\text { angel }\end{array}$ & 25 & 37 & 16 & 0 & 0 & 4,12 \\
\hline \multicolumn{7}{|l|}{ Punching } \\
\hline \multicolumn{7}{|l|}{ Line } \\
\hline -lelucon & 35 & 34 & 9 & 0 & 0 & 4,33 \\
\hline -MC & 36 & 35 & 7 & 0 & 0 & 4,37 \\
\hline \multicolumn{7}{|l|}{ Gimmick } \\
\hline -backsound & 40 & 37 & 1 & 0 & 0 & 4,50 \\
\hline -ekspresi & 49 & 23 & 5 & 0 & 1 & 4,53 \\
\hline Clip hanger & 39 & 31 & 6 & 2 & 0 & 4,37 \\
\hline
\end{tabular}

Sumber: olah data penulis (2019)

Keterangan: Indikator

Sub Variabel Kreatif
Produksi $(Y)$
Sangat Sering
Sering
Ragu-ragu
Tidak Sering
Sangat Tidak Sering
Nilai Mean

Indikator continuity tentang konsep acara mudah dimengerti saat menonton tayangan Mission X menunjukkan kesimpulan bahwa mayoritas responden menyatakan cukup tinggi dilihat dari 49 orang menjawab sangat setuju, jika diprosentase menunjukkan bahwa responden memberikan respon yang bagus terhadap indikator continuity-konsep acara dengan nilai tertinggi $62,8 \%$. Mean yaitu ratarata responden dengan nilai 4,40 menunjukkan bahwa responden mudah mengerti tentang konsep acara
Mission X. Median yaitu nilai tengah responden dengan nilai 5,00 menunjukkan bahwa konsep acara mudah dimengerti saat menonton tayangan Mission $\mathrm{X}$. Mode/modus yaitu nilai data yang memiliki frekuensi tertinggi dengan nilai 5 menunjukkan bahwa responden menganggap indikator continuitykonsep acara memiliki nilai yang sangat positif.

Indikator continuity tentang dialog pembawa acara sesuai tema acara saat menonton tayangan Mission X menunjukkan kesimpulan bahwa mayoritas responden menyatakan cukup tinggi dilihat dari 51 orang menjawab sangat setuju, jika diprosentase menunjukkan bahwa responden memberikan respon yang bagus terhadap indikator continuity-dialog pembawa acara dengan nilai tertinggi 65,4\%. Mean yaitu rata-rata responden dengan nilai 4,46 menunjukkan bahwa responden merasa dialog sesuai tema acara Mission X. Median yaitu nilai tengah responden dengan nilai 5,00 menunjukkan bahwa dialog sesuai tema saat menonton tayangan Mission $\mathrm{X}$. Mode/modus yaitu nilai data yang memiliki frekuensi tertinggi dengan nilai 5 menunjukkan bahwa responden menganggap indikator continuitydialog pembawa acara memiliki nilai yang sangat positif.

Indikator composition tentang gambar yang ditampilkan dalam tayangan Mission X menunjukkan kesimpulan bahwa mayoritas responden menyatakan cukup tinggi dilihat dari 47 orang menjawab sangat setuju, jika diprosentase menunjukkan bahwa responden memberikan respon yang bagus terhadap indikator continuity-gambar yang ditampilkan dengan nilai tertinggi 60,4\%. Mean yaitu rata-rata responden dengan nilai 4,40 menunjukkan bahwa responden merasa gambar yang ditampilkan dalam tayangan Mission X menarik. Median yaitu nilai tengah responden dengan nilai 5,00 menunjukkan bahwa gambar yang ditampilkan dalam tayangan Mission X menarik. Mode/modus yaitu nilai data yang memiliki frekuensi tertinggi dengan nilai 5 menunjukkan bahwa responden menganggap indikator compisiton-gambar memiliki nilai yang sangat positif.

Indikator composition tentang warna yang ditampilkan dalam tayangan Mission X tidak terlalu gelap atau terang menunjukkan kesimpulan bahwa mayoritas responden menyatakan cukup tinggi dilihat dari 44 orang menjawab sangat setuju, jika diprosentase menunjukkan bahwa responden memberikan respon yang bagus terhadap indikator composition-warna yang ditampilkan dengan nilai tertinggi 56,4\%. Mean yaitu rata-rata responden dengan nilai 4,49 menunjukkan bahwa responden merasa warna yang ditampilkan dalam tayangan Mission X tidak terlalu gelap atau terang. Median yaitu nilai tengah responden dengan nilai 5,00 menunjukkan bahwa warna yang ditampilkan dalam 
tayangan Mission X tidak terlalu gelap atau terang. Mode/modus yaitu nilai data yang memiliki frekuensi tertinggi dengan nilai 5 menunjukkan bahwa responden menganggap indikator compisiton-warna memiliki nilai yang sangat positif.

Indikator camera angle yang ditampilkan dalam tayangan Mission X seperti menonton langsung menunjukkan kesimpulan bahwa mayoritas responden menyatakan cukup tinggi dilihat dari 37 orang menjawab sangat setuju, jika diprosentase menunjukkan bahwa responden memberikan respon yang bagus terhadap indikator camera angle yang ditampilkan dengan nilai tertinggi 47,4\%. Mean yaitu rata-rata responden dengan nilai 4,12 menunjukkan bahwa responden merasa camera angle yang ditampilkan dalam tayangan Mission X seperti menonton langsung. Median yaitu nilai tengah responden dengan nilai 4,00 menunjukkan bahwa camera angel yang ditampilkan dalam tayangan Mission X seperti menonton langsung. Mode/modus yaitu nilai data yang memiliki frekuensi tertinggi dengan nilai 4 menunjukkan bahwa responden menganggap indikator camera angle memiliki nilai yang positif.

Indikator punching line tentang lelucon menghibur yang ditampilkan dalam tayangan Mission X menunjukkan kesimpulan bahwa mayoritas responden menyatakan cukup tinggi dilihat dari 35 orang menjawab sangat setuju, jika diprosentase menunjukkan bahwa responden memberikan respon yang bagus terhadap indikator punching line-lelucon yang ditampilkan menghibur dengan nilai tertinggi $44,9 \%$. Mean yaitu rata-rata responden dengan nilai 4,33 menunjukkan bahwa responden merasa lelucon yang ditampilkan dalam tayangan Mission X menghibur. Median yaitu nilai tengah responden dengan nilai 4,00 menunjukkan bahwa lelucon yang ditampilkan dalam tayangan Mission X menghibur. Mode/modus yaitu nilai data yang memiliki frekuensi tertinggi dengan nilai 5 menunjukkan bahwa responden menganggap indikator punching linelelucon memiliki nilai yang sangat positif.

Indikator punching line tentang pembawa acara tidak membosankan yang ditampilkan dalam tayangan Mission $\mathrm{X}$ menunjukkan kesimpulan bahwa mayoritas responden menyatakan cukup tinggi dilihat dari 36 orang menjawab sangat setuju, jika diprosentase menunjukkan bahwa responden memberikan respon yang bagus terhadap indikator punching line-pembawa acara tidak membosakan dengan nilai tertinggi 46,2\%. Mean yaitu rata-rata responden dengan nilai 4,37 menunjukkan bahwa responden merasa pembawa acara tidak membosankan yang ditampilkan dalam tayangan Mission X. Median yaitu nilai tengah responden dengan nilai 4,00 menunjukkan bahwa pembawa acara yang ditampilkan dalam tayangan Mission X tidak membosankan. Mode/modus yaitu nilai data yang memiliki frekuensi tertinggi dengan nilai 5 menunjukkan bahwa responden menganggap indikator punching line-pembawa acara tidak membosankan memiliki nilai yang sangat positif.

Indikator gimmick tentang backsound menarik yang ditampilkan dalam tayangan Mission X menunjukkan kesimpulan bahwa mayoritas responden menyatakan cukup tinggi dilihat dari 40 orang menjawab sangat setuju, jika diprosentase menunjukkan bahwa responden memberikan respon yang bagus terhadap indikator gimmick-backsound menarik dengan nilai tertinggi 51,3\%. Mean yaitu rata-rata responden dengan nilai 4,50 menunjukkan bahwa responden merasa backsound yang ditampilkan dalam tayangan Mission X menarik. Median yaitu nilai tengah responden dengan nilai 5,00 menunjukkan bahwa backsound yang ditampilkan dalam tayangan Mission $\mathrm{X}$ menarik. Mode/modus yaitu nilai data yang memiliki frekuensi tertinggi dengan nilai 5 menunjukkan bahwa responden menganggap indikator gimmick-backsound memiliki nilai yang sangat positif.

Indikator gimmick tentang ekspresi wajah menghibur yang ditampilkan dalam tayangan Mission X menunjukkan kesimpulan bahwa mayoritas responden menyatakan cukup tinggi dilihat dari 49 orang menjawab sangat setuju, jika diprosentase menunjukkan bahwa responden memberikan respon yang bagus terhadap indikator gimmick-ekspresi wajah menghibur dengan nilai tertinggi 62,8\%. Mean yaitu rata-rata responden dengan nilai 4,53 menunjukkan bahwa responden merasa ekspresi wajah pembawa acara yang ditampilkan dalam tayangan Mission X menghibur. Median yaitu nilai tengah responden dengan nilai 5,00 menunjukkan bahwa ekspresi wajah yang ditampilkan dalam tayangan Mission X sangat menghibur. Mode/modus yaitu nilai data yang memiliki frekuensi tertinggi dengan nilai 5 menunjukkan bahwa responden menganggap indikator gimmick-eksresi wajah memiliki nilai yang sangat positif.

Indikator clip hanger tentang responden penasaran dengan adegan berikutnya saat jeda iklan yang ditampilkan dalam tayangan Mission X menunjukkan kesimpulan bahwa mayoritas responden menyatakan cukup tinggi dilihat dari 39 orang menjawab sangat setuju, jika diprosentase menunjukkan bahwa responden memberikan respon yang bagus terhadap indikator clip hanger dengan nilai tertinggi 50,0\%. Mean yaitu rata-rata responden dengan nilai 4,37 menunjukkan bahwa responden merasa clip hanger yang ditampilkan dalam tayangan Mission X membuat penasaran. Median yaitu nilai tengah responden dengan nilai 4,50 menunjukkan bahwa clip hanger yang ditampilkan dalam tayangan Mission X membuat penasaran. Mode/modus yaitu nilai data 
yang memiliki frekuensi tertinggi dengan nilai 5 menunjukkan bahwa responden menganggap indikator clip hanger memiliki nilai yang sangat positif.

Tabel 3. Ringkasan Hasil Analisis Regresi Berganda

\begin{tabular}{|c|c|c|c|c|}
\hline Variabel & $\begin{array}{c}\text { Koef } \\
\text { Beta }\end{array}$ & thitung & $\begin{array}{c}\text { Signifika } \\
\text { n }\end{array}$ & Ket. \\
\hline $\mathrm{X} 1.1$ & 0,26 & 2,81 & 0,006 & Signifika \\
\hline Frekuensi & 0 & 3 & & $n$ \\
\hline X1.2 & 0,25 & 2,70 & 0,009 & Signifika \\
\hline Intensitas & 6 & 4 & & $\mathrm{n}$ \\
\hline X1.3 & 0,26 & 2,58 & 0,012 & Signifika \\
\hline Durasi & 7 & 7 & & $\mathrm{n}$ \\
\hline X1.4 & 0,22 & 2,30 & 0,024 & Signifika \\
\hline Isi Media & 1 & 9 & & $\mathrm{n}$ \\
\hline X1.5 & 0,17 & 2,04 & 0,045 & Signifika \\
\hline $\begin{array}{c}\text { Hubunga } \\
\mathrm{n} \\
\text { Individu } \\
\text { dengan } \\
\text { Media }\end{array}$ & 6 & 2 & & $\mathrm{n}$ \\
\hline$\alpha$ & & \\
\hline F-Hitung & & \multicolumn{3}{|l|}{$=13,676$} \\
\hline $\mathrm{R}$ & & \multicolumn{3}{|l|}{$=0,698$} \\
\hline F-Tabel & & \multicolumn{3}{|l|}{$=2,22$} \\
\hline Adjusted R & Square & \multicolumn{3}{|l|}{$=0,451$} \\
\hline t-tabel & & \multicolumn{3}{|l|}{$=1,990$} \\
\hline Signifikan & & \multicolumn{3}{|l|}{$=0,000$} \\
\hline
\end{tabular}

Sumber: olah data penulis (2019)

Dari hasil penghitungan kuisioner menunjukkan bahwa terdapat pengaruh yang signifikan antara variabel penggunaan media terhadap variabel produksi kreatif variety show Mission X Trans TV. Hal ini menunjukkan bahwa sub variabel penggunaan media yang terdiri dari frekuensi, intensitas, durasi, isi media, dan hubungan individu dengan media menunjukkan masing-masing memiliki pengaruh yang signifikan terhadap hasil produksi kreatif variety show Mission X Trans TV.

\section{KESIMPULAN}

Variabel penggunaan media yang terdiri dari frekuensi, instensitas, durasi, isi media, dan hubungan individu dengan media memiliki pengaruh yang besar terhadap kreatif produksi sebuah tayangan. Semakin sering masyarakat menonton acara tersebut maka membuktikan bahwa kreatifitas produksi acara tersebut semakin bagus. Dengan banyaknya masyarakat yang menonton tayangan Mission X, maka menunjukkan bahwa kreatif produksi acara tersebut semakin tinggi sehingga membuat masyarakat merasa tidak bosan untuk mengikuti tayangan Mission $\mathrm{X}$ setiap minggunya.
Dari hasil penghitungan kuisioner pada variabel penggunaan media, menunjukkan bahwa penggunaan media pada warga Perumahan Griya Permata Asri Tulungagung dapat dikatakan tinggi, hal ini dapat dilihat dari jawaban yang diberikan responden, mayoritas menonton tayangan Mission $\mathrm{X}$ dari awal sampai akhir, dan mengikuti setiap segmen dan ikut berpartisipasi secara aktif dalam media sosial.

Dengan adanya pengaruh yang signifikan antara penggunaan media terhadap hasil produksi kreatif variety show Mission X Trans TV menunjukkan bahwa tim produksi variety show Mission X sukses dalam mengemas tayangan tersebut menjadi menarik sehingga responden merasa kebutuhan yang diinginkan tercukupi.

\section{DAFTAR PUSTAKA}

Effendy, O. U. (2003). Ilmu Teori dan Filsafat Komunikasi. Bandung: PT. Remaja Rosdakarya.

Haslinda. (2016). PENGARUH PERENCANAAN $\begin{array}{lcr}\text { ANGGARAN } & \text { DAN } & \text { EVALUASI } \\ \text { ANGGARAN } & \text { TERHADAP } & \text { KINERJA }\end{array}$ ORGANISASI DENGAN STANDAR BIAYA SEBAGAI VARIABEL MODERATING PADA PEMERINTAH DAERAH KABUPATEN WAJO. Jurnal Ilmiah Akuntansi Peradaban, Vol. II No, 121.

N.R.A, C. (2010). 497-1493-1-PB.pdf. Perkembangan Media Penyiaran Televisi Menjadikan Televisi Sebagai Kebudayaan Masyarakat, Volume I n, 187-189.

Rahmadhani, M. (2014). MOTIF DALAM MENONTON PROGRAM VARIETY SHOW RUNNING MAN.

Ruslan, R. (2006). Manajemen Public Relations dan Media Komunikasi, Konsepsi dan Aplikasi. Jakarta: Raja Grafindo Persada.

Suparmo, L. (2017). Uses and Gratifications Theory dalam Media Sosial WA (WhatsApp), 1-11.

\section{PROFIL PENULIS}

Rosiana Andhikasari, lulusan Magister Ilmu Komunikasi (M.I.Kom) Program Pasca Sarjana Universitas Budi Luhur Jakarta tahun 2017 dan lulusan Ilmu Komunikasi (S.I.Kom) Fakultas Ilmu Sosial Dan Ilmu Politik Universitas Brawijaya Malang tahun 2013. 